University of Nebraska - Lincoln

DigitalCommons@University of Nebraska - Lincoln

USDA National Wildlife Research Center - Staff Publications
U.S. Department of Agriculture: Animal and Plant Health Inspection Service

July 2003

\title{
Predators on Red-winged Blackbird nests in eastern North Dakota
}

Richard S. Sawin

North Dakota State University, Fargo, Department of Biological Sciences

Mark W. Lutman

USDA/APHIS/WS National Wildlife Research Center, Mark.W.Lutman@aphis.usda.gov

George M. Linz

USDA/APHIS/WS National Wildlife Research Center, george_m_linz@yahoo.com

William J. Bleier

North Dakota State University, Fargo, Department of Biological Sciences

Follow this and additional works at: https://digitalcommons.unl.edu/icwdm_usdanwrc

Part of the Environmental Sciences Commons

Sawin, Richard S.; Lutman, Mark W.; Linz, George M.; and Bleier, William J., "Predators on Red-winged Blackbird nests in eastern North Dakota" (2003). USDA National Wildlife Research Center - Staff Publications. 244.

https://digitalcommons.unl.edu/icwdm_usdanwrc/244

This Article is brought to you for free and open access by the U.S. Department of Agriculture: Animal and Plant Health Inspection Service at DigitalCommons@University of Nebraska - Lincoln. It has been accepted for inclusion in USDA National Wildlife Research Center - Staff Publications by an authorized administrator of DigitalCommons@University of Nebraska - Lincoln. 


\title{
Predators on Red-winged Blackbird nests in eastern North Dakota
}

\author{
Richard S. Sawin, ${ }^{1,4}$ Mark W. Lutman, ${ }^{2}$ George M. Linz, ${ }^{3}$ and William J. Bleier ${ }^{1}$ \\ ${ }^{1}$ Department of Biological Sciences, North Dakota State University, Fargo, North Dakota 58105 USA \\ ${ }^{2}$ United States Department of Agriculture, Wildlife Services, Phoenix, Arizona 85029 USA \\ ${ }^{3}$ United States Department of Agriculture, National Wildlife Research Center, Great Plains Field Station, \\ Bismarck, North Dakota 58501 USA
}

Received 5 August 2002; accepted 20 December 2002

\begin{abstract}
Predation has consistently been identified as the most common cause of nest failure for Redwinged Blackbirds (Agelaius phoeniceus). During May and June, 2000 and 2001, we used infrared-triggered camera systems to identify potential nest predators on artificially relocated Red-winged Blackbird nests in eastern North Dakota. For some of the species observed, these observations represent the first documentation of predation on Red-winged Blackbird nests in the northern Great Plains.
\end{abstract}

\section{SINOPSIS. Depredadores de los nidos de Agelaius phoeniceus en Dakota del Norte}

La depredación ha sido identificada consistentemente como la causa mas común de la pérdida de nidos en la especie Agelaius phoeniceus. Durante mayo y junio de 2000 y 2001, utilizamos una cámara que se disparaba con rayos infrarojos para identificar los posibles depredadores en nidos del ave en discusión. El estudio se llevó a cabo en Dakota del Norte. Se documentaron un considerable número de visitantes a los nidos vigilados y depredación por parte de organismos previamente no descritos para las Grandes Planicies.

Key words: Agelaius phoeniceus, nest predation, North Dakota, predators, Red-winged Blackbird

Red-winged Blackbird (Agelaius phoeniceus) nests are commonly lost to a host of factors including abandonment, predation, starvation, bad weather, brood parasitism, and failure of nest support vegetation (Beletsky 1996). Of these factors, predation has been consistently identified as the major source of nest failure for Red-winged Blackbirds (Searcy and Yasukawa 1995). Summarizing 14 studies, Beletsky (1996) found that it is common for $30-50 \%$ of Red-winged Blackbird nests to be depredated.

Despite the frequency of predation on Redwinged Blackbird nests, observed acts of predation are rare (Knight et al. 1985; Sealy 1994). The reasons for nest failure can be difficult to infer from nest remains, particularly when a suite of potential predators has not been identified (Lariviere 1999). Potential predators are probably difficult for Red-winged Blackbirds to identify when making decisions about where to nest (Beletsky and Orians 1996). Once nests are established, however, male Red-winged

\footnotetext{
${ }^{4}$ Corresponding author. Current address: 3405 Baywood Lane, Greenville, North Carolina 27834 USA. Email: rsawin@yahoo.com.
}

Blackbirds spend a considerable amount of time engaged in anti-predator vigilance (Yasukawa et al. 1992). Predator identity can have important implications for breeding Red-winged Blackbirds. While Red-winged Blackbirds are known for chasing predators such as American Crows (Corvus brachyrhynchos), there appears to be little they can do to deter larger, more persistent, or nocturnal predators such as mink (Mustela vison), Black-billed Magpies (Pica pica), or raccoons (Procyon lotor, Knight et al. 1985; Yasukawa et al. 1992; Beletsky and Orians 1996; Pribil 1998). Often, researchers speculate about the identity of predators based on observations of suspected predators in the study area (Yasukawa et al. 1992). When researchers have attempted to identify nest predators on Redwinged Blackbird nests, common methods include direct observation (Knight et al. 1985), automatic cameras (Picman et al. 1988, 1993), and miniature video cameras (Pietz and Granfors 2000a).

In studies where predators on Red-winged Blackbirds nests have been identified, the predator community has varied by geographic region and by location within a particular habitat. Primary predators in different regions have in- 
cluded Marsh Wrens (Cistothorus palustris) in British Columbia (Picman et al. 1988), Blackbilled Magpies in Washington (Beletsky and Orians 1996) and raccoons in Ontario (Weatherhead 1995). Detailed studies have revealed that predator communities in some habitats may be more diverse than previously thought (Picman et al. 1993; Pietz and Granfors 2000a).

Red-winged Blackbirds nest in variety of habitats, and predator communities vary across their range. In the northern Great Plains, work has been done to identify predators on waterfowl nests (Johnson et al. 1989) and the nests of grassland passerines (Pietz and Granfors 2000a), but little definitive information is known about predators on Red-winged Blackbird nests (Besser et al. 1987). Our objectives for this study were to identify predators on Red-winged Blackbird nests in Barnes County, North Dakota, consider other possible, but unidentified, predators in the study area, and consider the implications of the predator community for breeding Red-winged Blackbirds in this region.

\section{METHODS}

We collected data regarding predation on Red-winged Blackbird nests while conducting a study on breeding Red-winged Blackbirds in eastern North Dakota during May and June of 2000 and 2001. The study was centered in Barnes County, which is in the central portion of the Drift Plains ecoregion (Stewart 1975). This is a prime agricultural area, with a mix of row crops and CRP grasslands interspersed with numerous temporary and seasonal wetlands. The Drift Plains ecoregion hosts a large population of breeding Red-winged Blackbirds that breed in both wetland and upland habitats. The observations described in this report took place in wetlands located within a $22-\mathrm{km}$ radius of Sanborn, North Dakota $\left(46^{\circ} 93^{\prime} \mathrm{N}, 98^{\circ} 24^{\prime} \mathrm{W}\right)$.

Evidence of predator identity was based on pictures captured by infrared camera systems used to monitor activities at artificially relocated Red-winged Blackbird nests containing three or four Red-winged Blackbird eggs. Each camera system consisted of a camouflaged Olympus ${ }^{\circledR}$ Infinity Mini DLX $35 \mathrm{~mm}$ camera connected to a Trailmaster ${ }^{\circledR}$ TM 1500 active infrared game monitoring system. When in place, an infrared beam was set above the nest. If the beam was broken by a visitor to the nest, the camera shutter was triggered and a picture was taken. Each system was programmed to achieve a minimum time delay of 1 min between photographs, and to record the time and date of each event. Cameras and relocated nests were placed in the vicinity of active Red-winged Blackbird nests, often in areas thought to contain nest predators. In order to capture evidence for a variety of predators, we typically placed only one or two camera systems in each of the wetlands used in this study.

After the initial set up, each camera system was monitored for $24 \mathrm{~h}$ to determine if a large number of false events was being recorded. If a normal number of events was recorded, the 35 $\mathrm{mm}$ camera was activated and the system was checked on a regular basis. A setup was removed if a predation event occurred, if false events became a problem, or if no activity was recorded for 7-10 d. Slides were viewed using a $35 \mathrm{~mm}$ slide projector, and the time, date, and the identity of photographed predators were noted. We estimated the least possible number of visits responsible for the pictures taken. For example, two consecutive pictures of a female Red-winged Blackbird separated by 1 min were considered as one visit. However, two consecutive pictures of female Red-winged Blackbirds separated by $6 \mathrm{~h}$ were considered two visits. The actual number of visits per species depends on a host of uncontrolled factors, and these numbers should be considered with caution. Cameras captured photographs of potential predators, and nest contents were monitored before and after nest visits. Even when nest contents were destroyed, the identity of the predator had to be inferred from the photographs because the actual predation event was not observed.

\section{RESULTS}

Trailmaster ${ }^{\circledR}$ TM 1500 active infrared game monitoring systems were active for one or more days at 27 nests between 31 May and 28 July 2000. Camera systems were active for a total of $162 \mathrm{~d}$ at 24 different wetlands. Photographic evidence documenting at least 55 unique visits was captured at 15 nests (Table 1). The majority of the documented visits were by Redwinged Blackbirds, probably due to the fact 
Table 1. Photographic evidence of visitors at artificially relocated Red-winged Blackbird nests.

\begin{tabular}{|c|c|c|}
\hline Visitor & $\begin{array}{l}\text { Number of } \\
\text { photographs }\end{array}$ & $\begin{array}{l}\text { Fewest possible } \\
\text { number of } \\
\text { unique visits }\end{array}$ \\
\hline \multicolumn{3}{|l|}{ Birds } \\
\hline $\begin{array}{l}\text { male Red-winged } \\
\text { Blackbird } \\
\text { female Red-winged }\end{array}$ & 11 & 11 \\
\hline Blackbirdb & 46 & 25 \\
\hline Common Grackle & 5 & 3 \\
\hline Marsh Wren & 6 & 6 \\
\hline Mourning Dove ${ }^{\mathrm{b}}$ & 1 & 1 \\
\hline fledgling Blackbird ${ }^{b}$ & 13 & 2 \\
\hline unknown & 3 & 3 \\
\hline \multicolumn{3}{|l|}{ Mammals } \\
\hline $\begin{array}{c}\text { white-tailed deer } \\
\text { (fawn })^{b}\end{array}$ & 2 & \\
\hline striped skunk & 1 & 1 \\
\hline raccoon & 1 & 1 \\
\hline
\end{tabular}

a Based on timing and visitor sequence that were potentially responsible for the number of pictures observed.

b Probably not predation-related visits (Picman et al. 1988; Pietz and Granfors 2001b).

that relocated nests were placed in areas near active Red-winged Blackbird nests. Red-winged Blackbirds sometimes destroy the nests of other species (Sealy 1994); however, intraspecific nest predation has not been documented in Redwinged Blackbirds (Picman et al. 1988) and would probably not occur under normal circumstances (i.e., without nest relocation). We suspect that the visits were made by Redwinged Blackbirds from the territories on which the relocated nests were placed. However, we kept relocated nests away from our primary study wetlands (where birds were banded and territory ownership was tracked) so we can not confirm the identity of these birds. There was no evidence of predation by Mourning Doves (Zenaida macroura) or white-tailed deer (Odocoileus virginianus) in this study. However, Pietz and Granfors (2000b) documented that whitetailed deer will depredate Red-winged Blackbird nests in some situations.

Photographic evidence of predation was obtained for four additional species (Fig. 1). Raccoons and striped skunks (Mephitis mephitis) were both photographed destroying nests. Both of these species were photographed at night, but they were observed in and around study wetlands during daylight hours as well. Common Grackles (Quiscalus quiscula) removed or shattered Red-winged Blackbird eggs, while Marsh Wrens typically punctured Red-winged Blackbird eggs.

In addition to the predators captured on 35 $\mathrm{mm}$ film, we made direct observations of predation on Red-winged Blackbird nests by two species. On 11 June 2001, MWL approached a nest with three $7-8 \mathrm{~d}$ old Red-winged Blackbird chicks and observed a plains garter snake (Thamnophis radix) attempting to swallow one of the chicks. On the videotape of a nest containing a 8-9 d old chick on 22 June 2001, a mink appeared on the videotape and quickly removed the chick from the nest (Fig. 1).

\section{DISCUSSION}

We identified a wide range of potential predators on Red-winged Blackbird nests representing varied taxonomic groups and different foraging habits. The predators identified in this study were expected based on previous reports about predators on Red-winged Blackbird nests (Knight et al. 1985; Picman et al. 1988, 1993; Beletsky and Orians 1996; Pribil 1998) and previous reports about nest predators in the northern Great Plains (Johnson et al. 1989; Pietz and Granfors 2000a). We present documentation for some species that were previously only suspected, but not confirmed, as predators on Red-winged Blackbird nests. In addition, this study represents the first documentation for many predators on Red-winged Blackbird nests in the northern Great Plains. It can be difficult to identify all of the potential nest predators in any area (Lariviere 1999); even extensive studies can fail to identify common predators (Pietz and Granfors 2000a). Still, it is clear that Redwinged Blackbird nests in our study area are depredated by a wide variety of predators.

Despite hundreds of hours in and around Red-winged Blackbird breeding areas, observations of direct predation were rare. Predation events can occur quickly, and many predators alter their behavior in the presence of investigators. The Trailmaster ${ }^{\circledR}$ camera systems captured more predation events, but had some drawbacks. Because the cameras were triggered by any activity, they could not be used at nests that were actively attended. As a result, the 

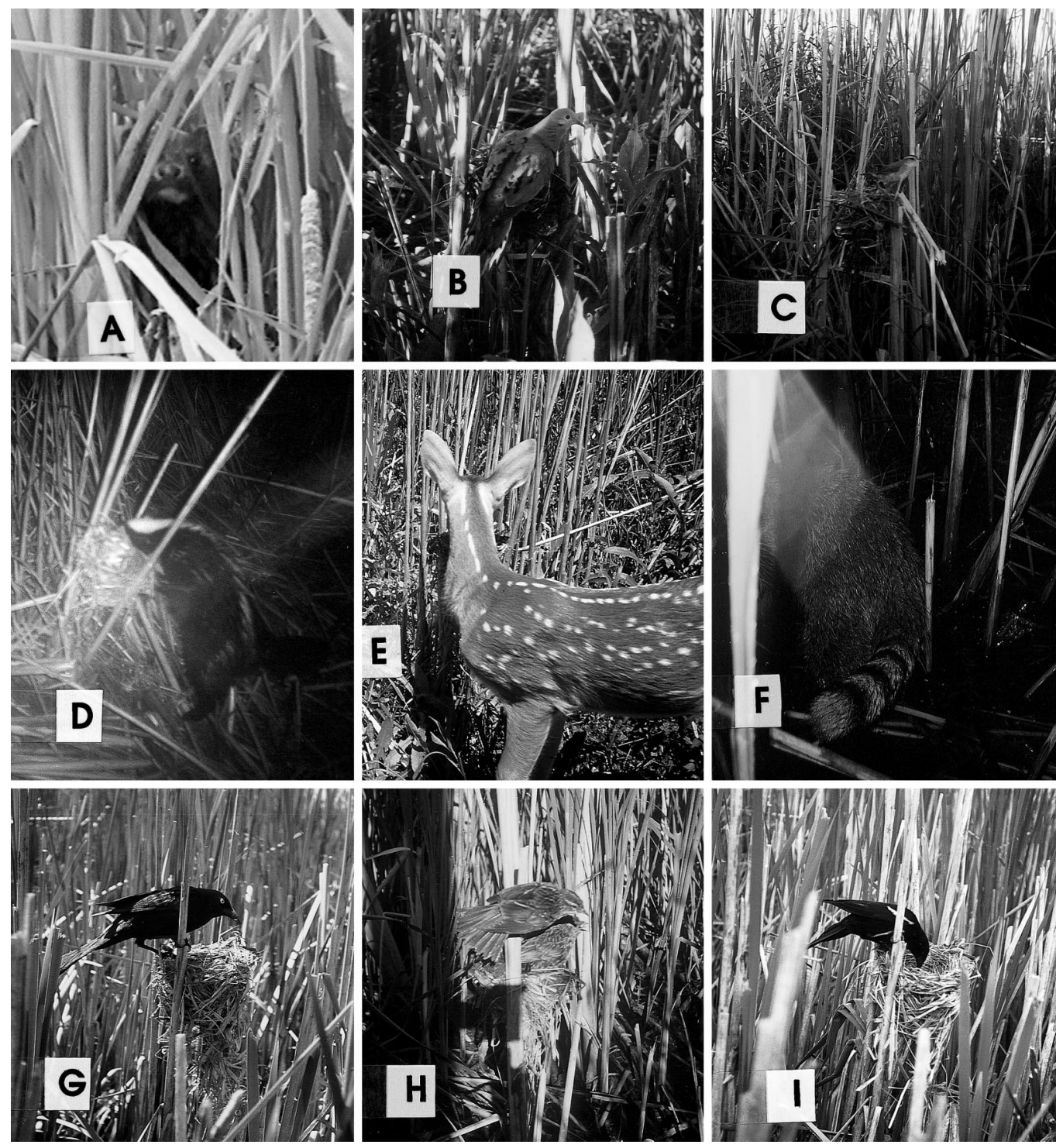

Fig. 1. Video (A) and photographic (B-I) evidence of visitors to active (A) and artificially relocated Redwinged Blackbird nests (B-I). Visitors included (A) mink, (B) Mourning Dove, (C) Marsh Wren, (D) striped skunk, (E) white-tailed deer, (F) raccoon, (G) Common Grackle, (H) female Red-winged Blackbird and fledgling, and (I) male Red-winged Blackbird. Not all visits were accompanied by predation events.

Trailmaster ${ }^{\circledR}$ system can only be used at nests with eggs (not chicks) and abandoned eggs may not have been attractive to some predators. In order to avoid false events caused by motion from vegetation, the sensitivity of the infrared trigger was set at a level that may have missed visits from smaller predators like Marsh Wrens, mice, or snakes. Other researchers have used video cameras to record events at active nests.
Video systems can be expensive and are likely to exhibit other types of bias (Pietz and Granfors 2000a). In order to collect evidence on a wide variety of predators, and to mitigate bias associated with specific methods, a variety of predator detection approaches should be used. Additional work is needed to determine the relative impact of each predator species.

Red-winged Blackbirds breeding at the edge 
of wetlands may experience more predation than those breeding over deeper water (Picman et al. 1993). In addition, Red-winged Blackbirds breeding close to or in upland areas are probably exposed to a more diverse group of predators than wetland breeding birds (Picman et al. 1993; Pribil 1998). In areas like the northern Great Plains, where Red-winged Blackbirds are excluded from prime wetland areas by Yellow-headed Blackbirds (Xanthocephalus xanthocephalus), breeding Red-winged Blackbirds might be exposed to more predation than their counterparts in regions where Yellow-headed Blackbirds do not breed. At the same time, areas of the northern Great Plains host large populations of breeding waterfowl, which may draw some predators away from Red-winged Blackbird nests (Johnson et al. 1989).

One side effect of the ubiquity of Redwinged Blackbirds is that some aspects of their breeding ecology have been studied in multiple populations (Beletsky 1996). In some cases, when differences between populations have been found, variation in the identity or abundance of predators has been suggested as one possible explanation (Weatherhead 1995). Identifying the potential predators on Redwinged Blackbird nests in a region is a step towards determining if different predator communities could account for observed differences between Red-winged Blackbird populations.

\section{ACKNOWLEDGMENTS}

This study was a part of the senior author's dissertation submitted to the Graduate School at North Dakota State University (NDSU). M. E. Biondini and G. L. Nuechterlein provided comments on earlier drafts of the manuscript. This project was conducted with the approval of the NDSU Institutional Animal Care and Use Committee (\#A0119) and under conditions outlined by a scientific collecting permit (\#MB 019065). Funding was provided jointly by the National Wildlife Research Center (Protocol QA-803), a unit within the Wildlife Services program of the United States Department of Agriculture, Animal and Plant Health Inspection Service, and by the Department of Biological Sciences at NDSU.

\section{LITERATURE CITED}

Beletsky, L. D. 1996. The Red-winged Blackbird: the biology of a strongly polygynous songbird. Academic Press, San Diego, CA.

_, AND G. H. ORIANS. 1996. Red-winged Blackbirds: decision making and reproductive success. University of Chicago Press, Chicago, IL.

Besser, J. F., O. E. Bray, J. W. DeGrazio, J. L. Guarino, D. L. Gilbert, R. R. Martinka, and D. A. DYSART. 1987. Productivity of Red-winged Blackbirds in South Dakota. Prairie Naturalist 19: 221232.

Johnson, D. H., A. B. Sargent, and R. J. GreenWOOD. 1989. Importance of individual species of predators on nesting success of ducks in the $\mathrm{Ca}$ nadian prairie pothole region. Canadian Journal of Zoology 67: 291-297.

Knight, R. L., S. Kim, and S. A. Temple. 1985. Predation of Red-winged Blackbird nests by mink. Condor 87: 304-305

LARIVIERE, S. 1999. Reasons why predators cannot be inferred from nest remains. Condor 101: 718-721.

Picman, J., M. Leonard, and A. Horn. 1988. Antipredation role of clumped marsh-nesting by Redwinged Blackbirds. Behavioral Ecology and Sociobiology 22: 9-15.

- , M. L. Milks, And M. Leptich. 1993. Patterns of predation on passerine nests in marshes: effects of water depth and distance from edge. Auk 110: 89-94.

Pietz, P. J., AND D. A. Granfors. 2000a. Identifying predators and fates of grassland passerine nests using miniature video cameras. Journal of Wildlife Management 64: 71-87.

- AND $-2000 \mathrm{~b}$. White-tailed deer (Odocoileus virginianus) predation on grassland songbirds. American Midland Naturalist 144: 419-422.

PRIBIL, S. 1998. Reproductive success is a misleading indicator of nest-site preferences in the Red-winged Blackbird. Canadian Journal of Zoology 76: 22272234.

Sealy, S. G. 1994. Observed acts of egg destruction, egg removal, and predation on nests of passerine birds at Delta Marsh, Manitoba. Canadian FieldNaturalist 108: 41-51.

Searcy, W. A., and K. Yasukawa. 1995. Polygyny and sexual selection in Red-winged Blackbirds. Princeton University Press, Princeton, NJ.

STEWART, R. E. 1975. Breeding birds of North Dakota. Tri-college Center for Environmental Studies, Fargo, ND.

Weatherhead, P. J. 1995. Effects on female reproductive success of familiarity and experience among male Red-winged Blackbirds. Animal Behaviour 49: 967-976.

Yasukawa, K., L. K. Whittenberger, and T. A. NielSEN. 1992. Anti-predator vigilance in the Redwinged Blackbird, Agelaius phoeniceus: do males act as sentinels? Animal Behaviour 43: 961-969. 